\title{
Effect of advanced manufacturing technology, concurrent engineering of product design, and supply chain performance of manufacturing companies
}

\begin{abstract}
As competition shifts away between competitors to supply chains, simultaneous sharing of technical expertise on product design is key to manufacturing success. Thus, purpose of this study is to examine the mediating effect of concurrent engineering of product design (CEPD) on the relationship between advanced manufacturing technology (AMT) and supply chain performance (SCP). The paper is a cross-sectional study, and data was collected among top managers of manufacturing companies. Cluster and systematic random sampling techniques were used to select the respondents. Structural equation modeling (Amos graphic) was used for analysis. The study found a positive relationship between advanced manufacturing technology and supply chain performance, advanced manufacturing technology and concurrent engineering of product design, and concurrent engineering of product design and supply chain performance. It also concluded that concurrent engineering of product design is a full mediator between advanced manufacturing technology and supply chain performance.
\end{abstract}

Keyword: Advanced manufacturing technology; Concurrent engineering of product design; Supply chain performance; Manufacturing companies 